\title{
A retrospective analysis of tularemia cases admitted to a tertiary care hospital
}

\author{
Ü̧̧üncü basamak săglık kuruluşuna başvuran tularemi olgularının \\ retrospektif analizi
}

Tanzer Korkmaz, ${ }^{1}$ Yusuf Özgür Biçer, ${ }^{2}$ Öcal Sırmatel, ${ }^{3}$ Fatma Sırmatel ${ }^{4}$

\begin{abstract}
${ }^{1}$ Department of Emergency Medicine, Medical Faculty of Abant İzet Baysal University, Bolu, Turkey
${ }^{2}$ Department of Otolaryngology, Medical Faculty of Abant İzet Baysal University, Bolu, Turkey

${ }^{3}$ Department of Radiology, Medical Faculty of Abant İzzet Baysal University, Bolu, Turkey

${ }^{4}$ Department of Infectious Diseases, Medical Faculty of Abant İzet Baysal University, Bolu, Turkey
\end{abstract}

\begin{abstract}
Objectives: In this study, we aimed to investigate the clinical and laboratory features of tularemia diseases.

Patients and Methods: Between January 2009 and June 2012, medical data of 89 patients (38 males, 51 females; mean age $36 \pm 1.9$ years; range 10 to 80 years) who were admitted to our hospital was retrospectively analyzed. Demographic characteristics of the patients, physical examination and laboratory findings and the treatment which they received were recorded. Descriptive statistical analysis was performed.
\end{abstract}

Results: Sixty-eight (76.4\%) patients were admitted to our hospital in 2010 and most of these referrals ( $n=64 ; 74.9 \%)$ were in winter (January, February and March). Of the patients, $84.7 \%$ were residing in rural areas and presented mostly with the complaints of high fever, sore throat, and swollen neck on admission. Cervical lymphadenopathy was observed in $83.1 \%$ of the patients.

Conclusion: Tularemia should be considered in the differential diagnosis for the patients living in endemic regions and presenting with high fever, sore throat and swollen neck. A multidisciplinary approach should be also adopted considered for the diagnosis, treatment, and prevention of the disease.

Key Words: Acute tonsillopharyngitis; lymphadenopathy; tularemia.

\begin{abstract}
Amaç: Bu çalışmada tularemi hastalığına ait klinik ve laboratuvar özellikler araştırıldı.

Hastalar ve Yöntemler: Ocak 2009 - Haziran 2012 tarihleri arasında hastanemize başvuran ve tularemi tanısı konulan 89 hasta (38 erkek, 51 kadın; ort. yaş 36 \pm 1.9 yıl; dağılım 10-80 yıl) retrospektif olarak değerlendirildi. Hastaların demografik özellikleri, fizik muayene ve laboratuvar bulguları ve almış oldukları tedavileri kaydedildi. Tanımlayıcı istatistiksel analiz yapıldı.
\end{abstract}

Bulgular: Hastaların 68'inin (\%76.4) 2010 yılında hastanemize başvurduğu ve başvuruların çoğunun ( $\mathrm{n}=64 ; \% 74.9)$ kış aylarında (Ocak, Şubat ve Mart) yapıldığı tespit edildi. Hastaların \%84.7'sinin kırsal kesimde yaşadığı ve en sık yüksek ateş, boğaz ağrısı ve boyunda şişlik yakınmaları ile başvurdukları tespit edildi. Servikal lenfadenopati hastaların $\% 83.1$ 'inde gözlendi.

Sonuç: Endemik bölgelerde yaşayan ve yüksek ateş, boğaz ağrısı ve boyunda şişlik ile başvuran hastalarda tularemi ayırıcı tanısı göz önünde bulundurulmalıdır. Ayrıca hastalığın tetkik, tedavi ve korunmasında multidisipliner bir yaklaşım benimsenmelidir.

Anahtar Sözcükler: Akut tonsillofarenjit; lenfadenopati; tularemia. 
Tularemia is a zoonotic infectious disease caused by the bacterium Francisella tularensis (F. tularensis). It was first isolated in 1912 by McCoy and Chapin in Tulare county in California. ${ }^{[1-4]}$ Initially evaluated under the Pasteurella and Brucella type, the bacterium was later named F. tularensis in 1947. Highly contagious F. tularensis is spread to humans by various vectors, such as rodents or arthropods, or by inhalation or direct contact with water contaminated with infected carcasses. No human-tohuman transmission has been reported. ${ }^{[5,6]}$ Seven different clinical forms of tularemia are reported to be present in humans: ulceroglandular, glandular, oculoglandular, oropharyngeal, intestinal, pneumonic, and typhoidal. ${ }^{[7,8]}$ The contagious properties of this organism caused it to be used for developing biological weapons as well. ${ }^{[6]}$

Seasonal variations in the incidences of tularemia have been observed both regionally and nationally in Turkey. ${ }^{[9]}$ Because of this, tularemia is a current subject in the fields of public health and preventative medicine. Determining the modes of transmission and possible vectors is particularly important for preventative medicine strategies.

In this study, we aimed to retrospectively evaluate the tularemia cases diagnosed and treated in our tertiary hospital, and to review the related literature.

\section{PATIENTS AND METHODS}

This was a descriptive cross-sectional study. Eightynine patients ( 38 males, 51 females; mean age $36 \pm 1.9$ years; range 10 to 80 years) who presented to our tertiary hospital and were diagnosed with tularemia between January, 2009 and June, 2012 were evaluated retrospectively. Patient demographics, including age, sex, occupation, residence, date of hospital visit, chief complaints (high fever, cough, sore throat, neck swelling, other), physical exam findings (lymphadenopathy (LAP), tonsillopharyngitis, LAP suppuration), and laboratory findings [sedimentation $(\mathrm{mm} / \mathrm{hr}), \mathrm{C}$-reactive protein (CRP) $(0.5-5 \mathrm{mg} / \mathrm{L}$ normal range), white blood cells (WBC) (4-10 10\%/L normal range), neutrophil percentage (2-7 10\% L normal range)], and treatment that they received prior to the hospital visit were recorded. Location, laterality (left or right), and number of cervical LAPs in patients who underwent neck ultrasonography (USG) were also recorded. The diagnosis of tularemia was made by serological testing and clinical findings. In the serological diagnosis, a micro-agglutination test (MAT) titer of greater than 1:160 was considered to be positive for tularemia as suggested by the Ankara Refik Saydam Public Health Institute.

Descriptive statistics were used to analyze the findings. The SPSS statistical software for Windows, version 17 was used for the statistical analyses (SPSS Inc., Chicago, Illinois, USA). With normally distributed data values were presented as mean \pm standard deviation (SD), and with data which is not distributed normally values were presented as median \pm standard error (SE).

\section{RESULTS}

When the age groups and sex were evaluated, the disease was found to be more common (prevalent) in males between 51 and 60 years of age $(n=10,27 \%)$, and in females between 31 and $40(n=15,30 \%)$ (Figure 1). When annual periods were considered, 68 patients $(76.4 \%)$ were seen in 2010, 15 (16.9\%) in 2009, five (5.6\%) in 2011 and one (1.1\%) during the first half of 2012. Figure 2 shows the seasonal variations in the number of patients, with the disease being more prevalent the winter months. No hospital admittance of a tularemia patient was detected in June and July.

Among all patients, $62(69.7 \%)$ were found to be living in rural areas, while 14 (15.7\%) in urban towns. For 13 patients (14.6\%), information regarding their location of residency could not be determined. The majority of the patients living in rural areas were from the Gerede (Bolu, Turkey) district ( $\mathrm{n}=47,52.8 \%)$.

Sixty-four (71.9\%) patients did not give any information related to occupation, while $11(12.4 \%)$ were housewives, six $(6.7 \%)$ were students, four $(4.5 \%)$ were farmers, two $(2.2 \%)$ were ranchers, one $(1.1 \%)$ was a public employee, and one (1.1\%) was a retiree.

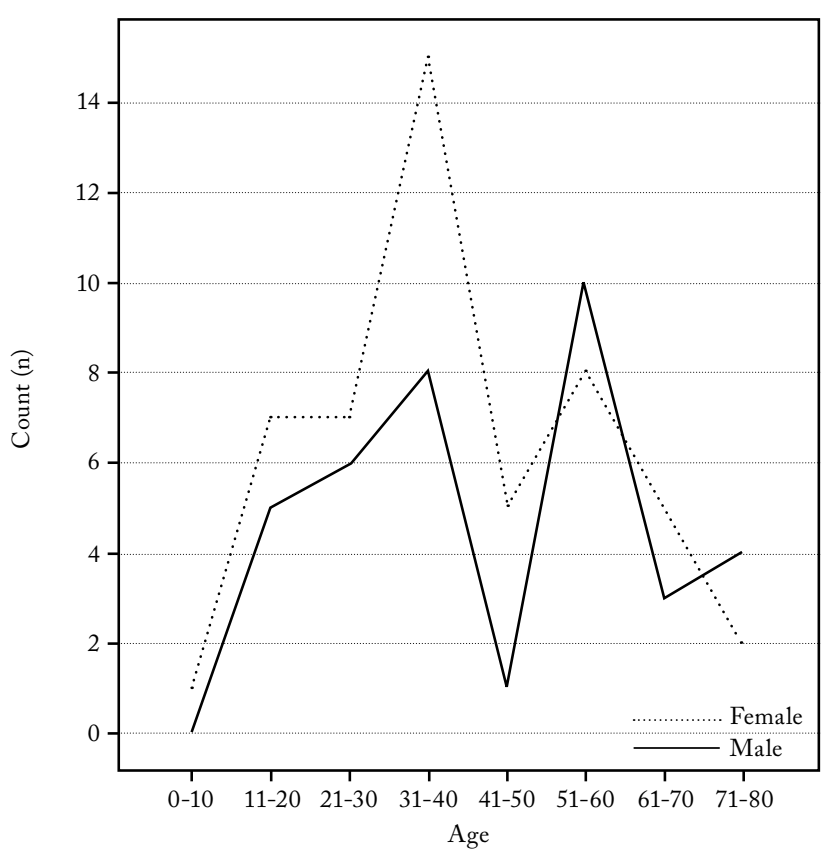

Figure 1. Age distribution of tularemia cases according to gender. 


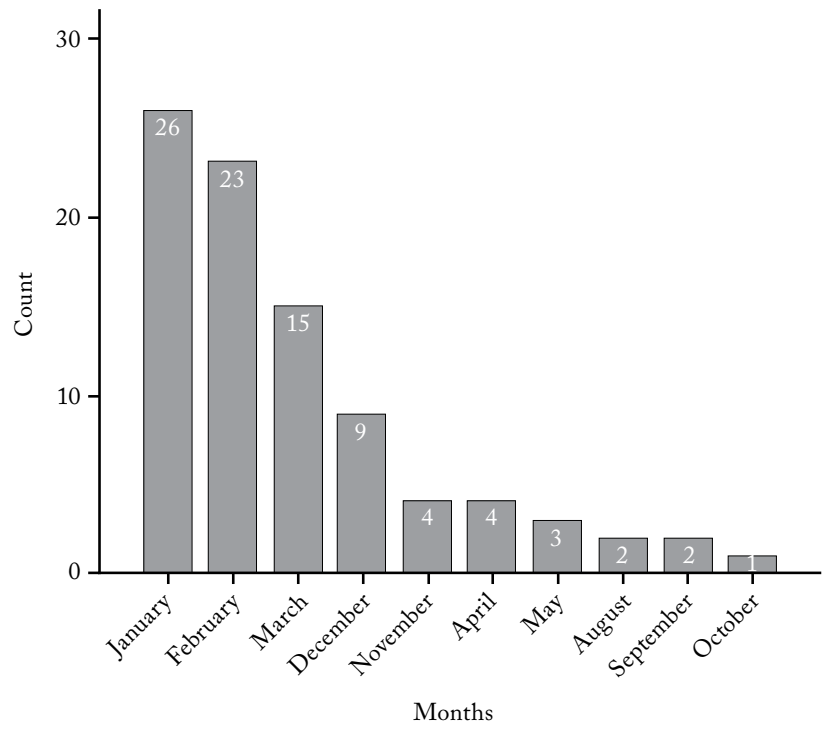

Figure 2. Distribution of tularemia cases by month.

When the clinics that patients presented to were considered, $57(64 \%)$ were seen at the infectious diseases clinic, $18(20.2 \%)$ at the ear-nose-throat, four $(4.5 \%)$ at emergency department, and 10 $(11.2 \%)$ at other clinics. While the chief complaints included high fever, sore throat, and neck swelling, in 74 patients $(83.1 \%)$ cervical LAP was determined during the physical exam (Table 1). Forty patients (44.9\%) had left sided LAP and 32 (36\%) had rightsided LAP, while two patients $(2.2 \%)$ had LAPs on both sides of the neck. In 15 patients (16.9\%), there was no record regarding the laterality of the LAP. Data about the neck USG examination was available for 29 patients (32.6\%). Of those, 26 had multi regional cervical LAPs (9 in Level 2, 2 in Level 3, 1 in Level 1, and 1 extending into Level 1, 2, and 3), one had a hypo-echoic abscess formation, and two had a single LAP presence.

There were 10 patients (11.2\%) with suppuration of LAP and of these patients five of them received antibiotic treatment before diagnosis of tularemia ( 4 of them using beta-lactam antibiotics).

The median duration between the onset of symptoms and the hospital visit was $15 \pm 2.11$ (95\% CI, 17.02-25.46) days (range 2-90 days). Two patients, who visited the hospitals 150 and 365 days after the onset of symptoms, respectively, were excluded from the study. Both of those patients, a 45-year-old housewife who had complaints for a year and a 78-year-old male who had complaints for 150 days, were living in the Gerede (Bolu, Turkey) district and both had LAPs in Level 2 zone in the neck. Both of those patients were found to have used an unknown type of antibiotic for an unknown period of time with no relief achieved in their symptoms.

Sixty (67.4\%) of the patients received antibiotic treatments prior to hospital admission, while $3(3.4 \%)$ had not. There was no information available for the antibiotic treatment for $26(29.2 \%)$ of the patients. Of the 60 who received therapy, 40 (44.9\%) used beta-lactam group antibiotics. The average period for receiving antibiotic treatment prior to hospital admission was $7 \pm 3.4$ days (range 3-15 days). Information related to the treatment regime after hospital admission following tularemia diagnosis was available for $71(79.8 \%)$ of the patients. Of all the patients treated with antibiotics, $60(67.4 \%)$ had a double antibiotic regimen, nine (10.1\%) had a single antibiotic regimen, and two (2.2\%) had a triple antibiotic regimen. The double and triple regimens consisted of various combinations of tetracycline,

\begin{tabular}{|c|c|c|c|c|c|c|}
\hline \multicolumn{7}{|c|}{$\begin{array}{c}\text { Table } \mathbf{1} \\
\text { Symptoms and signs of tularemia patients (on hospital admis }\end{array}$} \\
\hline \multirow[b]{2}{*}{ Symptoms and Signs } & \multicolumn{2}{|c|}{ Present } & \multicolumn{2}{|c|}{ Absent } & \multicolumn{2}{|c|}{ Not recorded } \\
\hline & $\mathrm{n}$ & $\%$ & $\mathrm{n}$ & $\%$ & $\mathrm{n}$ & $\%$ \\
\hline Neck swelling & 78 & 87.6 & 2 & 2.2 & 9 & 10.1 \\
\hline Sore throat & 49 & 55.1 & 7 & 7.9 & 33 & 37.1 \\
\hline Fever & 45 & 50.6 & 3 & 3.4 & 48 & 46.1 \\
\hline Cough & 3 & 3.4 & 9 & 10.1 & 77 & 86.5 \\
\hline Other* & 34 & 38.2 & - & - & 55 & 61.8 \\
\hline Lymphadenopathy & 74 & 83.1 & - & - & 15 & 16.9 \\
\hline Tonsillopharyngitis & 27 & 30.3 & 7 & 7.9 & 55 & 61.8 \\
\hline Suppuration of lymphadenopathy** & 10 & 11.2 & 3 & 3.4 & 76 & 85.4 \\
\hline
\end{tabular}


streptomycin, quinolone, gentamicin, and rifampicin. Among the most commonly used combinations were tetracycline-streptomycin and tetracycline-quinolone.

When the laboratory findings of the patients were evaluated, the average white blood cell (WBC) count upon admission was 9.1 $\pm 2.510 \% / \mathrm{L}$ (min: 4.9-max: 14.90), sedimentation was $42.9 \pm 28.1 \mathrm{~mm} / \mathrm{hr}$ (min: $3.0-\max : 111$ ), the median CRP was $18.2 \pm 4.7 \mathrm{mg} / \mathrm{L}$ (95\% CI, 19.4-38.5), and the median neutrophil percent was $56.8 \pm 1.4$ $10 \%$ L (95\% CI, 55.1-60.9). The WBC count was within the normal limits in 55 patients $(61.8 \%)$ and high in 34 patients (38.2\%), while the CRP was high in 50 patients $(56.2 \%)$ and within normal limits in 19 (21.3\%).

\section{DISCUSSION}

Tularemia became a major public health issue in Turkey once it appeared in Thrace, Marmara, and the Western Black Seas regions, followed by outbreaks, predominantly due to contaminated water, in other regions of the country. ${ }^{[10]}$ There have been reported cases in Thrace since 1936. One thousand and eighty cases have been detected in Bursa, Çanakkale, and Susurluk regions since 1988. ${ }^{[11-13]}$ The other cases were reported in Bilecik, Yalova, Samsun, Düzce, Ankara, Kastamonu, and Bartın provinces between 1998 and 2004. Twentyone cases were reported in Bilecik province in March 1998, 34 in Samsun-Havza in December 1999, 22 in Yalova in April 2000, 21 in Düzce in May 2000, 27 in Sinop-Yeşilyurt village in October 2000, 61 in Zonguldak region between 2004 and 2005, and 21 in Bolu-Gerede in 2001. ${ }^{[11,14,15]}$ There were 188 cases reported, almost all of them in the oropharyngeal form, in Kocaeli-Gölcük between December 2004 and May $2005{ }^{[5]}$ Tularemia epidemics are primarily seen in the rural regions. ${ }^{[16]}$ We detected a total of 89 cases in our study between 2009 and 2012, and the majority (69.7\%) of them were residing in rural areas. The year 2010 can be considered as an epidemic year with 68 patients seen. Increases followed by a continuous decline in the number of cases over the years are thought to be the result of effective treatment and containment strategies for the disease.

Tularemia is more commonly seen among farmers, veterinarians, herders, and hunters. In their study, Feldman et al. ${ }^{[17]}$ listed the risks for transmission as cutting crops where contaminated carcasses lie in the summer, tick bites, or contact. Özdemir et al. ${ }^{[18]}$ in their study conducted in Düzce, stated the likely source of transmission as cleaning water supplies contaminated with creek water, which was contaminated with infected carcasses. All tularemia cases reported after 2000 in Turkey are reported to be connected to spring water. ${ }^{[5,10]}$

Çağll et al ${ }^{[19]}$ reported the frequency of outbreaks peaking during November and December, whereas in another study conducted by Snowden et al., ${ }^{[20]}$ the peak period was between May and June. In our study, the 2010 epidemic, with 68 patients, was seen peaking during December, January, February, and March. The most common cause of transmission was stated to be tick bites in the study by Snowden et al., ${ }^{[20]}$ with patients residing in rural regions, possibly explaining the peak period during May and June. The modes of transmission are likely related to the time of the year. Since occupational information was missing in some records of the study participants, and since there was no recorded information on the type and sources for drinking water and water for use, we were not be able to comment on the modes of transmission of the disease in our study. However, we found that the majority $(69.7 \%)$ of our cases resided in rural regions, and the disease prevalence peaked during the winter months. Considering the literature data, it is reasonable to assume that the majority of our study subjects, who predominantly live in the rural regions, use spring water for drinking and daily use. . $^{[5,910,16]}$ The lack of proper infrastructure, contact of rodents with water sources, and insufficient chlorination render the transmission via water easier. The transmission of tularemia by ticks in our study can be ruled out as we see cases predominantly appear in the winter months in our region. While the predominant mode of transmission is contact with infected animals and ticks worldwide, the lack of chlorinated drinking water and use of spring water for daily needs are thought to be major causes of disease transmission in Turkey. ${ }^{[10]}$

Because of the high virulence of $F$. tularensis and difficulty in culturing, diagnosis is based mainly on clinic picture and serological tests to detect antibodies in patients' serum (micro-agglutination, tube agglutination or ELİSA). Antibodies against tularemia become detectable after two weeks in tularemia and reach highest level in 4-5 weeks. Micro-agglutination test is more sensitive than tube agglutination test. The test is accepted as positive when the serum titer $\geq 1: 160$ or fourfold increase in the serum titer in consecutive serum samples. ${ }^{[2,10,21]}$

The most common form of tularemia around the world is reported to be ulceroglandular, while we found that our study groups predominantly suffered from the oropharyngeal form. ${ }^{[9,21]}$ Various studies have reported that the oropharyngeal form of tularemia presents with a sore throat, neck swelling, and high fever, and that those complaints occur 20-51 days prior to the hospital admission..$^{[18,19,22,23]}$ In our study, high fever was present 
in 45 patients, LAP in 74 patients, and a sore throat in 49 patients. The median time between the onset of symptoms and the hospital admission was 15 days, which is shorter than the time period found in similar studies in the literature. There are important defects especially with regard symptoms and signs of the patients due to the lack of hospital records in our study.

The presence of LAP in the neck is a classical sign of the oropharyngeal form of tularemia. In two other studies, LAP was present in all of the cases most commonly on the left side and at Level 2. ${ }^{[5,19]}$ Similarly, 74 (83.1\%) of our patients had LAP with one-sided occurrence being the most common. Furthermore nine patients, among the ones who received a neck USG, had LAPs in Level 2. Of the 72 one-sided LAPs, 40 were left sided and 32 were right sided. Şencan et al. ${ }^{[24]}$ also reported left sided LAPs as being more common in their study. In a study conducted in Japan, the researchers commented that the reason for the more common occurrence of left sided axillary and brachial LAPs could be patients using the right hand when cooking, holding the possibly infected animals with their left hands. ${ }^{[25]}$ However, we think that the reasons for which LAPs occur on the left side more commonly seem to be more difficult to comment on. There are studies reporting the consumption of contaminated food and water as a source of transmission for oropharyngeal tularemia, and the inappropriate use of antibiotics (such as beta-lactam) causing the granulomatosis and caseation of cervical LAPs in the majority of patients. ${ }^{[14,26]}$ Most of our patients had used antibiotics, and suppurative lymphadenitis was observed more frequently in the ones that used beta-lactam group agents. Therefore appropriate antibiotics must be prescribed by physicians in regions where tularemia is endemic, and the disease must be considered in differential diagnosis in patients presenting with high fever, sore throat, and neck swelling. When we consider the spectrum of signs and symptoms in tularemia, tularemia patients may refer to different departments therefore it is important to approach tularemia cases in a multidisciplinary manner. Early initiation of treatment for tularemia is important for successful results. Aminoglycosides, tetracycline, and quinolones are the antibiotics used in tularemia. The first choice of treatment are aminoglycosides and 10-21 days of treatment period is proposed for all choices of antibiotics. ${ }^{[10]}$ In our study we could not assess the use of antibiotics, because we could not obtain the data about the antibiotic treatment in all cases.

The choice of routine laboratory examinations can vary in patients diagnosed with tularemia. Histopathological chronic granulomatous inflammation can be seen in the lymph nodes; however there may be no pathognomonic signs. The WBC count was found within normal limits in $52 \%$ of the patients in a study conducted by Çağlı et al., ${ }^{[19]} 50 \%$ by Snowden et al., ${ }^{[20]} 73 \%$ in Wilke ${ }^{[5]}$ and $26 \%$ by Ulu Kilıç et al., ${ }^{[16]}$ while in our study it was $61 \%$. There have been significant differences in the sedimentation and CRP rates in other studies. While Ak1nc1 et al. ${ }^{[22]}$ found high sedimentation in 26 cases (83\%) and high CRP in 24 cases (75\%), Ulu K1lı̧ et al. ${ }^{[16]}$ found high sedimentation in 10 cases $(66 \%)$ and high CRP in eight cases (53\%). Wilke ${ }^{[5]}$ on the other hand, found high sedimentation rates in varying degrees in all of their cases. We had high sedimentation rates (average $42.9 \mathrm{~mm} / \mathrm{hr}$.) in $72 \%$ of our patients and high CRP values in $56 \%$ of our patients.

We can conclude that there is no specific and easyto-use routine laboratory or radiological examination for the diagnosis of tularemia except the micro-agglutination test.

In conclusion, as in other parts of the world, tularemia is an important public health issue in Turkey because of its potential to cause epidemics from time to time. Apart from developing protocols for the diagnosis and treatment of the disease, joint plans must be created to support the development of preventative strategies.

Tularemia must be considered in differential diagnosis, especially in the patients presenting to the EDs with acute tonsillopharyngitis and neck swelling. Specific serological tests must be ordered for the diagnosis in endemic regions, and a multidisciplinary approach must be adopted for the diagnosis and treatment of tularemia patients.

\section{Declaration of conflicting interests}

The authors declared no conflicts of interest with respect to the authorship and/or publication of this article.

\section{Funding}

The authors received no financial support for the research and/or authorship of this article.

\section{REFERENCES}

1. Sjöstedt A. Tularemia: history, epidemiology, pathogen physiology, and clinical manifestations. Ann N Y Acad Sci 2007;1105:1-29.

2. Ellis J, Oyston PC, Green M, Titball RW. Tularemia. Clin Microbiol Rev 2002;15:631-46.

3. Nano FE. Francisella: microbiology and microbial infections. Vol. 2, 9th ed. New York: Oxford University Pres Inc.; 1998.

4. Tärnvik A, Berglund L. Tularaemia. Eur Respir J 2003;21:361-73.

5. Wilke A. Tularemi. ANKEM Dergisi 2006;20: 222-226.

6. Dennis DT, Inglesby TV, Henderson DA, Bartlett JG, 
Ascher MS, Eitzen E, et al. Tularemia as a biological weapon: medical and public health management. JAMA 2001;285:2763-73.

7. Dlugaiczyk J, Harrer $\mathrm{T}$, Zwerina J, Traxdorf $\mathrm{M}$, Schwarz S, Splettstoesser W, et al. Oropharyngeal tularemia--a differential diagnosis of tonsillopharyngitis and cervical lymphadenitis. Wien Klin Wochenschr 2010;122:110-4. doi: 10.1007/s00508-009-1274-8.

8. Surveillance CDfICUPH: Centers for disease control and previntion 1997;46:56.

9. Akalin H, Helvaci S, Gedikoğlu S. Re-emergence of tularemia in Turkey. Int J Infect Dis 2009;13:547-51. doi: 10.1016/j.ijid.2008.09.020.

10. Kilic BS, Battal İ. Tularemi hastalığının kontrolü için saha rehberi. In: 799. Edited by Temel Sağlık Hizmetleri Genel Müdürlüğü ZHDB, Sağllk Bakanlığı. Ankara: Başak Matbaacılık ve Tanıtım Hiz. Ltd. Şti.; 2011.

11. Gedikoglu S. Pasteurella, francisella, bordetella. In: Willke Topçu A, Söyletir G Doğanay M, editörler. Enfeksiyon hastalıkları ve mikrobiyolojisi. İstanbul: Nobel Tip Kitabevi; 2000. s. 1658-66.

12. Helvaci S, Gedikoğlu S, Akalin H, Oral HB. Tularemia in Bursa, Turkey: 205 cases in ten years. Eur J Epidemiol 2000;16:271-6.

13. Kılıçturgay K, Gökırmak F, Gedikoğlu S, Helvacı S, Töre O, Tolunay Ş. Bursa'da Tularemi epidemisi. Turkish Journal of Infection 1989;3:149-56.

14. Celebi G, Baruönü F, Ayoğlu F, Cinar F, Karadenizli A, Uğur $\mathrm{MB}$, et al. Tularemia, a reemerging disease in northwest Turkey: epidemiological investigation and evaluation of treatment responses. Jpn J Infect Dis 2006;59:229-34.

15. Gürcan S, Otkun MT, Otkun M, Arikan OK, Ozer B. An outbreak of tularemia in Western Black Sea region of Turkey. Yonsei Med J 2004;45:17-22.

16. Ulu Kılıç A, Kılıç S, Sencan I, Ciçek Şentürk G, Gürbüz $\mathrm{Y}$, Tütüncü EE, et al. A water-borne tularemia outbreak caused by Francisella tularensis subspecies holarctica in Central Anatolia region. [Article in Turkish] Mikrobiyol
Bul 2011;45:234-47.

17. Feldman KA, Stiles-Enos D, Julian K, Matyas BT, Telford SR 3rd, Chu MC, et al. Tularemia on Martha's Vineyard: seroprevalence and occupational risk. Emerg Infect Dis 2003;9:350-4.

18. Ozdemir D, Sencan I, Annakkaya AN, Karadenizli A, Guclu E, Sert E, et al. Comparison of the 2000 and 2005 outbreaks of tularemia in the Duzce region of Turkey. Jpn J Infect Dis 2007;60:51-2.

19. Cağlı S, Vural A, Sönmez O, Yüce I, Güney E. Tularemia: a rare cause of neck mass, evaluation of 33 patients. Eur Arch Otorhinolaryngol 2011;268:1699-704. doi: 10.1007/ s00405-011-1722-8.

20. Snowden J, Stovall S. Tularemia: retrospective review of 10 years' experience in Arkansas. Clin Pediatr (Phila) 2011;50:64-8. doi: 10.1177/0009922810381425.

21. Gürcan S. Francisella tularensis and tularemia in Turkey. [Article in Turkish] Mikrobiyol Bul 2007;41:621-36.

22. Akıncı E, Ulgen F, Kılıç S, Yılmaz S, Yıldız S, Ozdemir B, et al. Evaluation of tularemia cases originated from Central Anatolia, Turkey. [Article in Turkish] Mikrobiyol Bul 2011;45:762-4.

23. Chitadze N, Kuchuloria T, Clark DV, Tsertsvadze E, Chokheli M, Tsertsvadze N, et al. Water-borne outbreak of oropharyngeal and glandular tularemia in Georgia: investigation and follow-up. Infection 2009;37:514-21. doi: 10.1007/s15010-009-8193-5.

24. Sencan I, Sahin I, Kaya D, Oksuz S, Ozdemir D, Karabay O. An outbreak of oropharyngeal tularemia with cervical adenopathy predominantly in the left side. Yonsei Med J 2009;50:50-4. doi: 10.3349/ymj.2009.50.1.50.

25. Ohara Y, Sato T, Fujita H, Ueno T, Homma M. Clinical manifestations of tularemia in Japan--analysis of 1,355 cases observed between 1924 and 1987. Infection 1991;19:14-7.

26. Gürcan Ş, Uzun C, Karagöl Ş, Karasalihoğlu AR, Otkun M. The first tularemia case in Thrace Region of Turkey in the last 60 years. Turk J Med Sci 2006; 36:127-8. 